\title{
The Prosody of Símákonde Relative Clauses ${ }^{1}$
}

\author{
Sophie Manus \\ CNRS (Dynamique du Langage Laboratory) \& Lumière Lyon 2 University - \\ UMR 5596
}

\begin{abstract}
Símákonde is an Eastern Bantu language (P23) spoken by immigrant Mozambican communities in Zanzibar and on the Tanzanian mainland. Like other Makonde dialects and other Eastern and Southern Bantu languages (Hyman 2009), it has lost the historical Proto-Bantu vowel length contrast and now has a regular phrase-final stress rule, which causes a predictable bimoraic lengthening of the penultimate syllable of every Prosodic Phrase. The study of the prosody / syntax interface in Símákonde Relative Clauses requires to take into account the following elements: the relationship between the head and the relative verb, the conjoint / disjoint verbal distinction and the various phrasing patterns of Noun Phrases. Within Símákonde noun phrases, depending on the nature of the modifier, three different phrasing situations are observed: a modifier or modifiers may (i) be required to phrase with the head noun, (ii) be required to phrase separately, or (iii) optionally phrase with the head noun.
\end{abstract}

\section{Introduction}

This paper investigates the prosody/syntax interface in Símákonde Relative Clauses. I will start in Section 2 by giving some background on Símákonde, presenting its genetic affiliation, its geographic range, the existing studies available currently on various Makonde dialects and the data displayed here. In Section 3, I will examine stress and phrasing and inventory the number of Prosodic Phrases contained in Noun Phrases (NPs) made of a noun and one modifier and in NPs made of a noun and more than one modifier. Then, in Section 4, I will detail the structure and the morphology of relative clauses,

1 I would like to thank Laura Downing and Annie Rialland, the co-directors of our Franco-German ANR/DFG Research Project, my Símákonde consultants Yoáána Píliisi and his family, Cédric Patin for his tireless interest in Símákonde, Crisney Lane for her careful proofreading and the audience at the 2009 Paris Bantu Psyn / SynPhonI workshop for their valuable comments, namely Larry Hyman, Chuck Kisseberth and Thilo C. Schadeberg. 
giving the morphology of subject and object relatives. Finally, in Section 5, I will discuss the prosody of subject and object relative clauses and propose an analysis of the complex phrasing possibilities displayed by relatives.

\section{Background on Símákonde}

\subsection{Genetic affiliation}

Makonde is an Eastern Bantu language coded as P23 in Guthrie's referential classification (1948), which has been confirmed by Maho in 2003.

\subsection{Geographic range}

Símákonde is a variety of Makonde spoken by immigrant Mozambican communities in Zanzibar (Unguja island) and on the Tanzanian mainland (Dar es Salaam, Bagamoyo, Tanga).

It is claimed to have been rather protected from external linguistic influences and seems to be much less permissive than other dialects in the phrasing options that it offers (cf. Patin \& Rialland 2006).

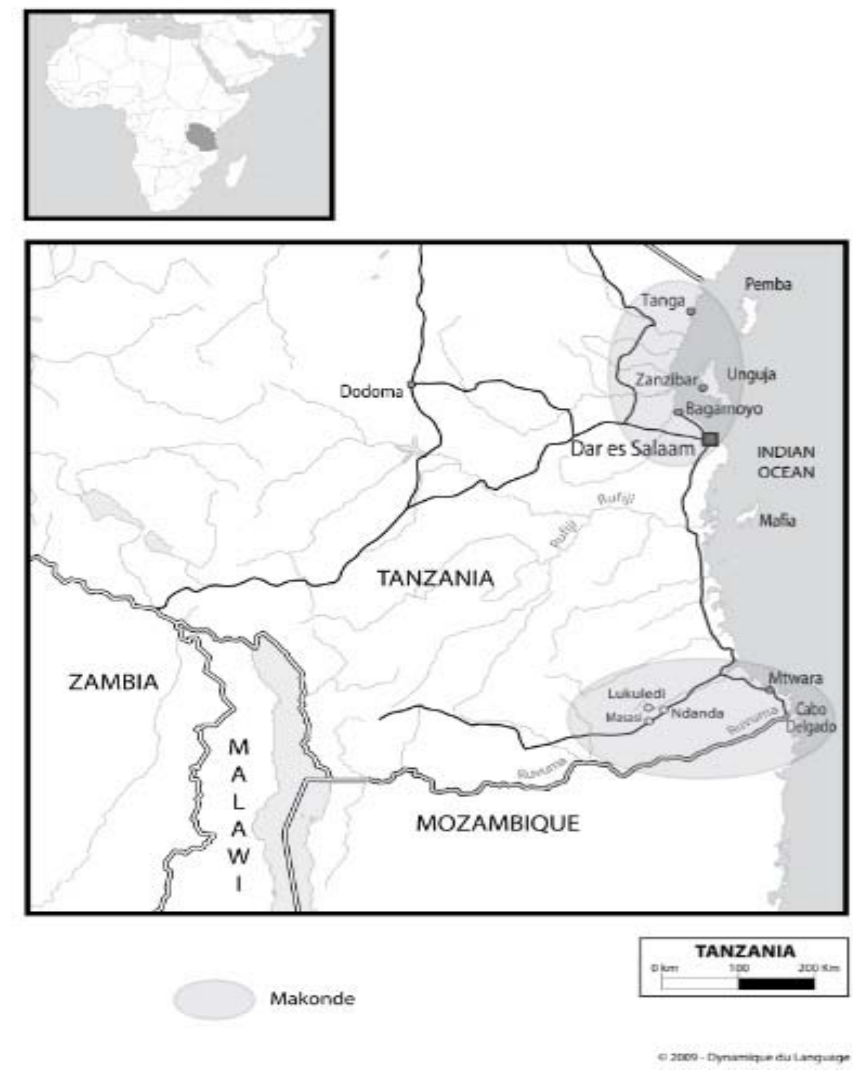

Figure 1: Map of the Makonde speaking area ${ }^{2}$

2 C Dynamique du Langage Laboratory 2009, edited by the author in 2010. 


\subsection{Existing studies on various Makonde dialects}

Quite a few articles and books on various dialects of Makonde are currently available : Odden 1990a and 1990b on Chimaraba and Chimahuta respectively, which are spoken in Southern Tanzania, Liphola 2001 on Shimakonde, spoken in Southern Mozambique, Manus 2003 on Símákonde, spoken in Mozambican communities settled in Northern \& Central Eastern Tanzania \& in Zanzibar, Devos 2004 on Kimakwe, spoken in Northern Mozambique, and Kraal 2005 on Chinnima, spoken in Southern Tanzania.

\subsection{Data}

All data presented here have been elicited and recorded by the author from Yoáána Píliisi and his relatives in Tanzania in 2000, 2003, 2008, 2009 and 2010.

\section{Phrasing}

\subsection{Stress}

Like other Makonde dialects and other Eastern and Southern Bantu languages (Hyman 2009), Símákonde has lost the historical Proto-Bantu vowel length contrast and now has a regular phrase-final stress rule, which causes a predictable lengthening of the penultimate syllable of every Prosodic Phrase. The penult lengthened by stress is bimoraic.

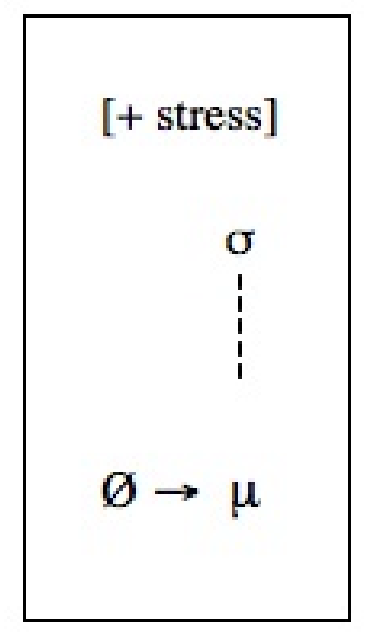

Figure 2: Penult lengthening rule

Examples in (1) show penultimate lengthening in Símákonde. 
(1) a. kúlúúma 'to bite'

b. kúlúmúúla 'to cut'

c. kúlúmúláánga 'to cut into small pieces'

d. kúlúmúlángííla 'to cut into small pieces for someone'

\subsection{To phrase or not to phrase}

The main question is to find out what constitutes a Prosodic Phrase (P-Phrase) in the language and what does not. Prosodic Phrases will be indicated with parentheses as shown in example (2) ${ }^{3}$.

$$
\begin{array}{ll}
\text { (sílóólo) (síkúmeêne) } & \text { (sindiîgwa) } \\
7^{4} \text {.mirror 7.big } & \text { 7.past.fall } \\
\text { '(A/the) big mirror fell' } &
\end{array}
$$

In this example made of a noun, an adjective and a verb, there are three distinct Prosodic Phrases, each element constituting an independent P-Phrase.

Let us first have a look at Noun Phrases (NPs) containing one modifier.

\subsubsection{Noun Phrases (NPs) made of a noun and one modifier}

A Noun Phrase made of a noun and one modifier can either form a single Prosodic Phrase or two distinct Prosodic Phrases.

Depending on the nature of the modifier, three different phrasing situations are observed: demonstratives are required to phrase with the head noun, adjectives, genitives and numerals are required to phrase separately, and possessives and intensifiers optionally phrase with the head noun (i.e. both a single P-Phrase and two P-Phrases are in these cases accepted by the speakers).

3 The following abbreviations are used in this paper :

$\begin{array}{llll}\text { Adj } & \text { Adjective } & \text { Obj } & \text { Object } \\ \text { Dem } & \text { Demonstrative } & \text { OM } & \text { Object Marker } \\ \text { CO } & \text { Connective } & \text { PL } & \text { Plural } \\ \text { Dis dei } & \text { Discourse Deictic } & \text { Poss } & \text { Possessive } \\ \text { Gen } & \text { Genitive } & \text { ProN } & \text { Pronoun } \\ \text { H } & \text { High tone } & \text { Prest } & \text { Present } \\ \text { Int } & \text { Intensifier } & \text { P-Phrase } & \text { Prosodic Phrase } \\ \text { Loc } & \text { Locative } & \text { Rel } & \text { Relative } \\ \text { Mod } & \text { Modifier } & \text { SG } & \text { Singular } \\ \text { Neg } & \text { Negative } & \text { SM } & \text { Subject Marker } \\ \text { NP } & \text { Noun Phrase } & \text { Suff } & \text { Suffix } \\ \text { Num } & \text { Numeral } & \text { TAM } & \text { Tense Aspect Mood marker } \\ & & \text { V } & \text { Verb }\end{array}$

$4 \quad$ Numbers refer to the Bantu Noun Classes. 


\section{2. 1. 1. (Noun + demonstrative $)=>$ one $P$-Phrase}

If the modifier is a demonstrative, it must phrase with the noun as shown in (3) a. and can never phrase separately as shown in (3) b.
a. (Noun + Dem)
(líjémbé aliilá)
5.hoe Dem $5^{5}$
'that hoe'
b. $*$ (Noun $)+($ Dem $)$

There are three different demonstratives in Símákonde (proximal, distal and anaphoric) and they all phrase exactly the same way. The demonstrative given in (3) a. is the distal one.

\section{2. 1. 2. (Noun) + (adjective, genitive or numeral) $=>$ two $P$-Phrases}

If the modifier is an adjective (4), a genitive (5) or a numeral (6), it can never phrase with the noun.

a. (Noun $)+$ (Adj)

(lyoônga) (líkúmeêne)

5.arrow 5.big

'(a) big arrow'

b. $*($ Noun + Adj $)$

(5)
a. (Noun $)+($ Gen $)$
(lyoônga) (lyá jkoôngwe)
5.arrow 5.CO 1.woman
'the woman's arrow'

b. *(Noun + Gen $)$

5 The point (.) marks a morphematic boarder (as in "5.hoe" there is a clear cut between "5", the class prefix li- and "hoe", the noun stem -jembe). Contrarily, Dem5 only indicates the presence of a demonstrative in class 5 and does not mean that the class marker is suffixed. I gloss "Dem5" to simplify when the structure is a bit more complex, as here: $a$-li-la actually corresponds to Dem-5-Dem. 
(6)
a. (Noun ) + (Num)
(lyoônga) (liímo)
5.arrow 5.one
'one arrow'
b. *(Noun + Num $)$

Numerals do behave like adjectives morphologically speaking (they take the same concords) and prosodically speaking (since they never phrase with the noun they modify).

\section{2. 1. 3. Noun + possessive or intensifier $=>$ one or two $P$-Phrases ${ }^{6}$}

If the modifier is a possessive or an intensifier (meaning "himself, herself, itself"), it can either phrase with the noun and constitute a single prosodic phrase with it as in (7) a. and (8) a. or not phrase with the noun and be parsed in an independent P-Phrase as in (7) b. and (8) b.

(7)

$$
\begin{array}{lll}
\text { a. } & \text { (Noun }+ & \text { Poss) } \\
\text { (iposó } & \text { yaángu) } \\
\text { 9.present } & \text { 9.possSG1 } \\
\text { 'my present', } &
\end{array}
$$

b. (Noun) + (Poss)

(ipooso) (yáangu)

9.present 9.possSG1

'my present'

(8) a. (Noun + Int)

(ípósó yeene)

9.present 9.int

'the present itself'

b. (Noun) + (Int)

(ipooso) (yéene)

9.present 9.int

'the present itself'

\footnotetext{
${ }^{6}$ The question of the semantic difference between (Noun $\mathrm{X}+$ modifier $\mathrm{Y}$ ) constituting a single P-Phrase as in (7) a. and (8) a. and (Noun X) + (modifier Y) constituting two separate P-Phrases as in (7) b. and (8) b. is too complex to be summarized briefly in this paper.
} 
Note that it is always possible to add a verb in the examples (3), (4), (5), (6), (7) and (8) cited above.

Whatever happens in the subject Noun Phrase prosodically, the verb will always constitute an independent Prosodic Phrase as shown in the examples (9) a. and (9) b. It will never phrase with the preceding Noun Phrase, as shown in (9) c., even if the Noun Phrase is restricted to only a noun, not followed by any modifier, as shown in (9) d. and (9) e.

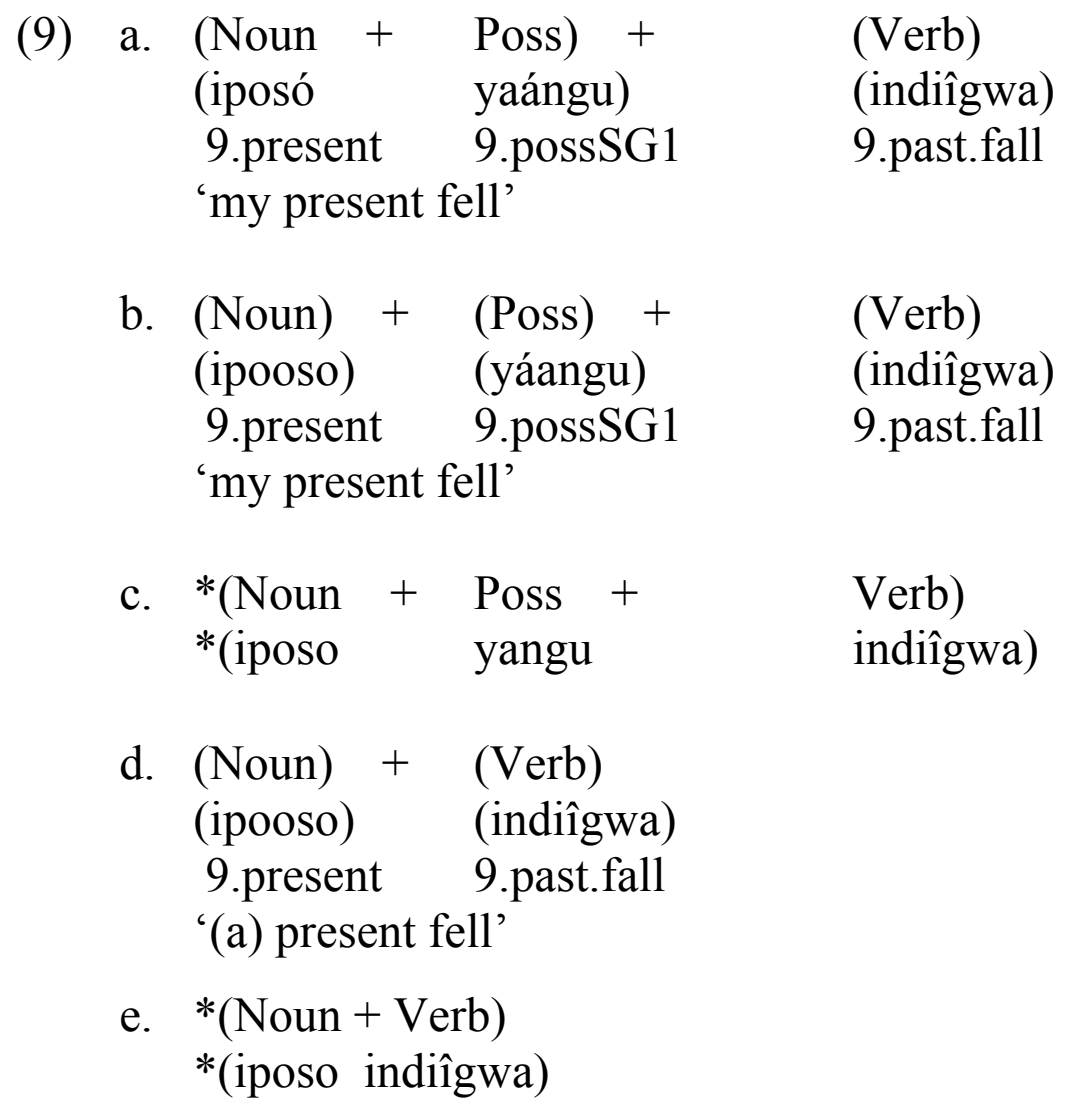

Note that if a Noun Phrase and the verb that follows never phrase together *(Noun Phrase + Verb), so-called conjoint verbs do phrase with what follows (Verb + Noun Phrase), whether what follows is a subject pronoun, an object noun or Noun Phrase, an adverb or an interrogative (Manus 2007). The example in (10) a. illustrates the case of a conjoint verb phrasing with its object noun.
a. (Conjoint Verb + Object Noun) (ngúsúmá sílóólo) (SG1.buy 7.mirror
'I am buying (a) mirror'
b. *(Conjoint Verb) $+($ Object Noun $)$ 
According to Buell (2006), "the terms conjoint and disjoint are due to Meeussen (1959). (...) The conjoint form cannot appear clause-finally, while the disjoint form canonically does appear in clause-final position."

Creissels $(1996,1997)$ uses the terms "conjunctive" and "disjunctive". According to him (1997), "(...) only the disjunctive form can be used in final sentence position and more generally in prepausal position, whereas in nonprepausal position both forms can occur (...)".

(11) below summarizes the various phrasing options in a Noun Phrase made of a noun and a single modifier, whether the modifier is an adjective, a genitive, a numeral, a demonstrative, a possessive or an intensifier.

\begin{tabular}{|c|c|c|}
\hline 2 P-Phrases & 1 P-Phrase & 1 or 2 P-Phrase(s) \\
\hline (N) $+($ Adj) & (N + Dem) & $\begin{array}{c}(\mathrm{N}+\text { Poss }) \\
\text { or } \\
(\mathrm{N})+(\text { Poss })\end{array}$ \\
\hline (N) $+($ Gen) & & $\begin{array}{c}\text { N }+ \text { Int }) \\
\text { or } \\
\text { (N) }+(\text { Int })\end{array}$ \\
\cline { 3 - 3 } & &
\end{tabular}

Let us now have a look at Noun Phrases made of a Noun and more than one modifier.

\subsubsection{Noun Phrases (NPs) made of a noun and more than one modifier}

In Noun Phrases made of a noun and more than one modifier, the Noun Phrases can either be split into more than one Prosodic Phrase or constitute a single Prosodic Phrase. Let us first look at the cases when the presence of more than one modifier creates more than one P-Phrases.

In 2007, Downing \& Mtenje established that in Chichewa "NPs which contain more than one modifier are generally parsed into more than one Phonological Phrase (...)".

This applies in Símákonde in many cases, as shown in the following examples. A Noun Phrase made of a noun and two modifiers can either constitute three distinct P-Phrases as in 3. 2. 2. 1. (as many P-Phrases as there are elements in the utterance) or only two P-Phrases as in 3.2.2.2. 
3. 2. 2. 1 . Noun + two modifiers $=>$ three P-Phrases $:($ Noun $)+(\bmod )+(\bmod )$

In (12) a. and (13) a., the Noun Phrases made of a noun and two different modifiers (adjective and numeral or possessive and numeral) are parsed into three distinct P-Phrases and could not phrase together as shown in (12) b. and (13) b.

$$
\begin{aligned}
& \text { a. (Noun) }+ \text { (Adj) }+ \text { (Num) } \\
& \text { (víjúulu) (vídíkídiîki) (viviíli) } \\
& \text { 8.hat 8.small 8.two } \\
& \text { 'two small hats' } \\
& \text { b. } \quad *(\text { Noun }+ \text { Adj }+ \text { Num }) \\
& \text { a. (Noun) }+ \text { (Poss) }+ \text { (Num) } \\
& \text { (vádyóóko) (váako) (vaviíli) } \\
& \text { 2.child 2.possSG2 2.two } \\
& \text { 'your two children' } \\
& \text { b. } *(\text { Noun }+ \text { Poss }+ \text { Num })
\end{aligned}
$$

Remember that possessives can also phrase together with the noun as shown above in (7) a., (9) a. and as you will also see in (15) a. and (17) a.

If a verb is added in (12) a. or (13) a., it will constitute an independent Prosodic Phrase as you can see in (14) a. (and in (9) above).

$$
\begin{aligned}
& \text { a. (Noun) }+ \text { (Poss) }+ \text { (Num) }+ \text { (Verb) } \\
& \text { (vádyóóko) (váangu) (vaviíli) (vandaiída) } \\
& \text { 2.child 2.possSG1 2.two 2.fut.come } \\
& \text { 'my two children will come' } \\
& \text { b. } *(\text { Noun }+ \text { Poss }+ \text { Num }+ \text { Verb })
\end{aligned}
$$

\section{2. 2. 2. Noun + two modifiers $=>$ two P-Phrases $:($ Noun + mod $)+($ mod $)$}

A Noun Phrase made of a noun and two different modifiers, a possessive and an adjective for example, can also be parsed into only two P-Phrases, as you can see in (15) a. 


$$
\begin{aligned}
& \text { a. (Noun + Poss) + (Adj) } \\
& \text { (lijembé lyaáko) (lídíkídiîki) } \\
& \text { 5.hoe 5.possSG2 5.small } \\
& \text { 'your small hoe' } \\
& \text { b. } *(\text { Noun }+ \text { Poss }+ \text { Adj })
\end{aligned}
$$

Let us now look at longer Noun Phrases, made of a noun and three modifiers. They can either constitute four distinct P-Phrases as in 3. 2. 2. 3. (as many PPhrases as there are elements in the utterance) or only three P-Phrases as in 3. 2. 2. 4 .

3. 2. 2. 3. Noun + three modifiers $=>$ four P-Phrases :

$($ Noun $)+($ mod $)+($ mod $)+($ mod $)$

The following example in (16) a. illustrates the case of a Noun Phrase, made of a Noun and three distinct modifiers (a numeral, an adjective and an adverb), that is parsed into four distinct P-Phrases.

Note that it cannot constitute a single P-Phrase as shown in (16) b.

$$
\begin{aligned}
& \text { a. (Noun) }+ \text { (Num) }+(\text { Adj })+(\text { Adv }) \\
& \text { (vílóólo) (viviíli) (vídíkídiîki) (nameêne) } \\
& \text { 8.mirror 8.two 8.small very } \\
& \text { 'two very small mirrors' } \\
& \text { b. } *(\text { Noun }+ \text { Num }+ \text { Adj }+ \text { Adv })
\end{aligned}
$$

\section{2. 2. 4. Noun + three modifiers $=>$ three $P$-Phrases :}

$($ Noun + mod $)+($ mod $)+($ mod $)$

The example in (17) a. illustrates the case of a Noun Phrase, made of a Noun and three distinct modifiers (a possessive, an adjective and an adverb), that is parsed into three distinct P-Phrases, the head noun and the first modifier phrasing together.

Note that it cannot constitute a single P-Phrase as illustrated in (17) b.
a. (Noun + Poss $)+($ Adj $)+(A d v)$ (sílóngó saángu) (síkúmeêne) (nameêne)
b. *(Noun + Poss + Adj + Adv) 
Examples (12), (13), (14), (15), (16) and (17) above have shown various cases in which an NP made of a noun and more than one modifier is necessarily parsed into more than one P-Phrase and could not constitute a single P-Phrase. Let us now consider the cases when an NP made of a noun and more than one modifier can be parsed into a single P-Phrase.

\section{2. 2. 5. Noun + more than one modifier $=>$ one P-Phrase :}

$($ Noun $+\bmod +\bmod +\bmod )$

As summarized and discussed by Downing \& Mtenje (to appear), Kanerva (1990) and Truckenbrodt $(1995,1999)$ both analysed prosodic phrasing in Chichewa (Bantu, N30) and claimed that "All NPs, no matter how long and complex, are parsed into a single Phonological Phrase"7.

This actually works as an exception only in Símákonde, when the last modifier is a demonstrative ${ }^{8}$, since Noun Phrases made of a noun and two, three or four modifiers are always parsed into a single Prosodic Phrase when the last modifier is a demonstrative.

This phenomenon in Símákonde could be formalized as follows :

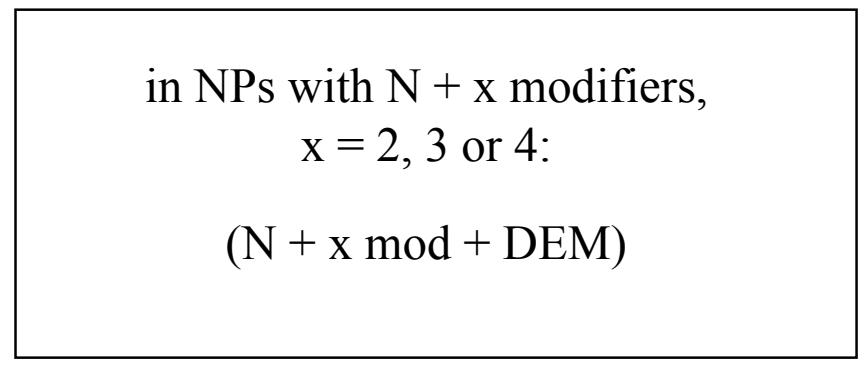

Examples (19) and (20) clearly show the amazing phrasing power of the final demonstrative that activates both the phrasing process and a High plateau neutralizing the various tone patterns of all the other elements of the Noun Phrase, ie the noun and all its modifiers : numeral, possessive, adjective, etc.

$$
\begin{aligned}
& \text { (Noun }+ \text { Num }+ \text { Poss }+\quad \text { DEM) } \\
& \text { (sílóngó símó } \quad \text { sángú } \\
& \text { 7.mirror 7.one } \\
& \text { 'this one mirror of mine' }
\end{aligned}
$$

7 Note that the prosodic situation in Chichewa is much more complex than that, as shown in Downing and Mtenje (to appear) who demonstrate "that Kanerva (and Truckenbrodt) only reached this conclusion about Chichewa because they only considered NPs that consist of a noun followed by a single nonclitic modifier".

8 Any of the three existing demonstratives (proximal, distal or anaphoric). 


\begin{tabular}{|c|c|c|c|c|}
\hline $\begin{array}{l}\text { (Noun + } \\
\text { (vílóngó }\end{array}$ & $\begin{array}{l}\text { Adj }+ \\
\text { víkúméné }\end{array}$ & $\begin{array}{l}\text { Gen } \\
\text { vyá }\end{array}$ & $\begin{array}{r}+ \\
\text { náswé }\end{array}$ & $\begin{array}{l}\text { Num } \\
\text { vívílí }\end{array}$ \\
\hline 8.pot & 8.big & 8.Gen & white & 8.two \\
\hline
\end{tabular}

Let us have a look at what would happen to (20) tonally and prosodically if one withdrew the final demonstrative:

$$
\begin{array}{lllll}
(\text { Noun })+ & (\text { Adj) }+ & (\text { Gen }) & + & + \text { (Num) } \\
\text { (viloôngo) } & \text { (víkúmeêne) } & \text { (vyá } & \text { naáswe) } & \text { (viviíli) } \\
\text { 8.pot } & \text { 8.big } & \text { 8.Gen } & \text { white } & \text { 8.two } \\
\text { 'two big white pots' } & & &
\end{array}
$$

In (21), without the final demonstrative, there are four distinct Prosodic Phrases that each have their full tone patterns and their bimoraic penult.

In (20), it is only the presence of the demonstrative that reduces the four PPhrases to only one with one phrase-final bimoraic penult only and a High plateau neutralizing the tone patterns.

The most probable explanation of the High plateau in (21) is the fact that the demonstrative triggers the presence of an initial High tone which is a trace of the ancient augment (Bantu pre-prefix) which does not exist in Símákonde anymore.

In conclusion, it has been shown in this section that Noun Phrases which contain more than one modifier are generally parsed into more than one Prosodic Phrase, except if the last modifier is a demonstrative.

We will now consider Relative Clauses.

\section{Structure and morphology of the Relative Clauses}

In this section I will give a brief presentation of the morphology of Subject and Object Relatives.

\subsection{Subject Relatives}

There is no relative pronoun in Símákonde.

A Subject Relative Clause is identified by specific verb forms that are dedicated to the relative context and have the following structure : 
(22)

$$
\text { SM I or SM II }{ }^{9}-\mathrm{TAM}-\mathrm{V}
$$

Example of a subject relative verb form:

$$
\text { (áloôla) }
$$

a.Ø.lola

1.prest.watch

'who is watching'

Compare this to the equivalent subject non-relative verb form:

$$
\text { (aykulóóla) }
$$

a.jku.lola

1.prest.watch

'he/she is watching'

\subsection{Object Relatives}

An Object Relative Clause is identified by specific verb forms that are dedicated to the relative context and introduced by the connective $-a$ as shown here :

$$
\mathrm{CO}-a+\mathrm{V}
$$

Note that the connective $-a$ is also used in genitive constructions similar to the one shown in (5) above. Genitive constructions and object relative clauses introduced by the connective $-a$ are all parsed into separate P-Phrases.

In Object Relative Clauses, there is a morphological distinction between animates in $1 / 2^{10}$ and animates in other genders or non-animates.

Let us first consider animates in $1 / 2$.

9 There are two series of subject markers in Símákonde: SM I \& SM II. See Manus (2003) for a detailed inventory.

10 In Símákonde, only the animates in $1 / 2$ will trigger an animate concord in $1 / 2$ and require the presence of an Object Marker. Animates in 9/10 such as animals for example will only trigger a concord in 9/10 and will not require the presence of an Object Marker. 


\subsubsection{Animates in $1 / 2$}

Animates take the first series of Subject Markers and a compulsory Object Marker as summarized here :

(26)

$$
\mathrm{CO}-a+\mathrm{SM} \mathrm{I}-\mathrm{TAM}-\mathrm{OM}-\mathrm{V}
$$

Example of an object relative verb form:

$$
\begin{aligned}
& \text { (wá nínóola }{ }^{11} \text { ) } \\
& \text { w.a ni.Ø.n.lola } \\
& \text { 1.CO SG1-prest.OM1.watch } \\
& \text { 'whom I am watching' }
\end{aligned}
$$

Compare this to object non-relative verb forms, with (29) and without (28) an object marker:

(28) (ninkulóóla)

$$
\text { ni.yku.lola }
$$

SG1.prest.watch

'I am watching'

(29) (ninkunnóóla)

ni.yku.n.lola

SG1.prest.OM1.watch

'I am watching him'

\subsubsection{Animates in other genders and non-animates}

Animates that are not in $1 / 2$ and non-animates take the second series of Subject Markers and no Object Marker :

11 Note that the insertion of the nasal Object Marker nasalizes the initial consonant of the verb stem that follows. 
(30)

$$
\mathrm{CO}-a+\text { SM II - TAM - OM - V }
$$

Example of a relative verb form:

$$
\begin{aligned}
& \text { (vyá válóola) } \\
& \text { vy-a va.Ø.lola } \\
& \text { 8.CO 2-prest.watch } \\
& \text { 'that they are watching' }
\end{aligned}
$$

Compare this to the equivalent non-relative verb form:

$$
\begin{aligned}
& \text { (vankulóóla) } \\
& \text { va.yku.lola } \\
& \text { 2.prest.watch } \\
& \text { 'they are watching' }
\end{aligned}
$$

\section{Prosody of Relative Clauses}

After summarizing the general phrasing principles in Símákonde in Section 3 and the structure and morphology of Relative Clauses in Section 4, I will now present the prosody of Relative Clauses.

\subsection{Subject Relatives}

Just as in the non-relative context, where subject and verb never phrase, the head noun and the relative verb never phrase together.

A noun followed by various modifiers phrases exactly as seen in Section 3 above.

But the situation between a conjoint relative verb and its object(s) is a bit more complex as we will see in the next examples.

Let us start with a simple example ${ }^{12}$.

12 In the following examples, the glosses of the verb forms are simplified to focus on the phrasing. Note that the TAMs of the conjoint and the disjoint presents are $-\varnothing$ - and the TAM of the past is -ndi-. 
(Noun) + (Rel Verb) + (Verb):

$$
\begin{aligned}
& \text { (ńdyóóko) (átukuûta) (andiîgwa) } \\
& \text { 1.child 1.prest.run 1.past.fall } \\
& \text { 'the child who is running (just) fell' }
\end{aligned}
$$

In the absence of an object in (33), nothing phrases. Head, relative verb and verb constitute three distinct P-Phrases.

Let us now add an object to the relative verb.

$$
\text { (Noun) + (Rel Verb + Obj Noun) + (Verb): }
$$

$$
\begin{aligned}
& \text { (ńdyóóko) (ánnola ńnéembo) (andiîgwa) } \\
& \text { 1.child 1.prest.OM1.watch 1.elephant 1.past.fall } \\
& \text { 'the child who is watching (the) elephant (just) fell' }
\end{aligned}
$$

The relative verb spontaneously takes its conjoint form to phrase with its object noun and constitutes a single P-Phrase with it.

Note that if we add modifiers to the subject noun, they all phrase together if the last modifier is a demonstrative as seen in Section 3.2.2.5.

$$
(\text { Noun + Adj + Dem })+(\text { Rel Verb + Obj Noun })+(\text { Verb }):
$$

$\begin{array}{llll}\text { (ńdyókó ńdíkídíkí ááju) } & \text { (áńnola } & \text { ńnéembo) } & \text { (andiîgwa) } \\ \text { 1.child 1.small Dem.1 } & \text { 1.prest.OM1.watch } & \text { 1.elephant } & \text { 1.past.fall } \\ \text { 'this small child who is watching (the) elephant (just) fell' } & \end{array}$

Let us now have a look at what happens when one adds a modifier to the object noun of the relative verb form. We will first look at an example with an animate object in 1 (nnéembo = elephant). Note the presence of the Object Marker in the verb.

$($ Noun + Adj + Dem $)+($ Rel Verb + Obj Noun + Dem $)+($ Verb $):$

$$
\begin{aligned}
& \text { (ńdyókó ńdíkídíkí ááju) (áńnola ńnémbó } \\
& \text { 1.child 1.small Dem.1 1.prest.OM1.watch 1.elephant } \\
& \text { aiijá) (andiîgwa) } \\
& \text { Dem1 1.past.fall } \\
& \text { 'this small child who is watching that elephant (just) fell' }
\end{aligned}
$$


In this case, the relative conjoint verb form phrases with both the noun and its modifier, since the final modifier here is a demonstrative.

Let us now look at a similar example with a non-animate object in 7 (siínu, thing).

$\begin{array}{clllll}\text { (ńdyókó } & \text { ńdíkídíkí } & \text { ááju) } & \text { (álola } & \text { sínú } & \text { asiilá) } \\ \text { 1.child } & \text { 1.small } & \text { Dem.1 } & \text { 1.prest.watch } & \text { 7.thing } & \text { Dem7 }\end{array}$

(andiîgwa)

1.past.fall

'this small child who is watching that thing (just) fell'

Of course the phrasing does not change and the relative verb form appears under its conjoint form and phrases with its object noun and the final demonstrative.

As we have seen in Section 3.2.2.5. above, a final demonstrative has a strong phrasing power on what precedes it.

Let us now look in (38) at an example in which the modifier following the object noun of the relative verb is not a demonstrative - necessarily constituting a single P-Phrase with its head noun - but a possessive, that can optionally phrase or not phrase with its head noun.

Note that in this sentence, the object is an animate in 10 (dímbúúdi, goats). As a consequence it behaves like a non-animate since it does not activate a concord in 1/2 nor the presence of an Object Marker.

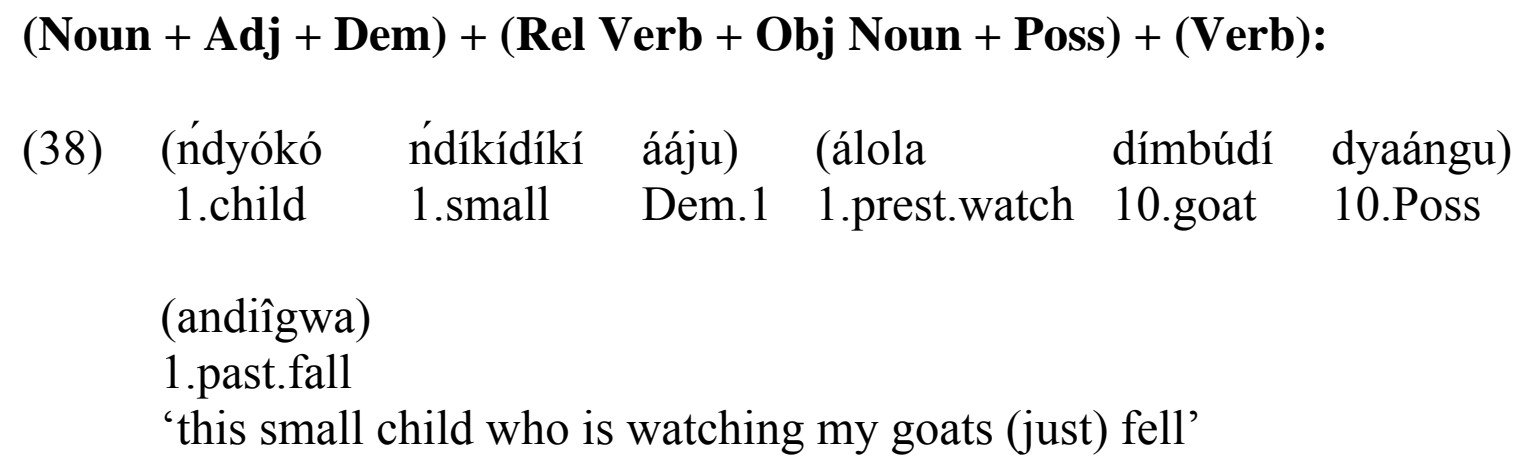

$\begin{array}{clllll}\text { (ńdyókó } & \text { ńdíkídíkí } & \text { ááju) } & \text { (álola } & \text { dímbúdí } & \text { dyaángu) } \\ \text { 1.child } & \text { 1.small } & \text { Dem.1 } & \text { 1.prest.watch } & \text { 10.goat } & \text { 10.Poss }\end{array}$

(andiîgwa)

1.past.fall

'this small child who is watching my goats (just) fell'

In this case, the relative verb is conjoint and phrases again with its object noun and the modifier (the possessive) that follows.

We have seen in Section 3 that in the case of possessives, the head noun and its modifier can either phrase together and form a single P-Phrase or phrase separately and form two distinct P-Phrases. It is the same here?

Apparently, the situation in a relative context is different since the only other phrasing option accepted by the speakers is one where the possessive still phrases with the noun it modifies but the relative verb phrases separately in its disjoint form, as you can see in (39). 
$($ Noun + Adj + Dem $)+($ Rel Verb $)+($ Obj Noun + Poss $)+($ Verb $):$

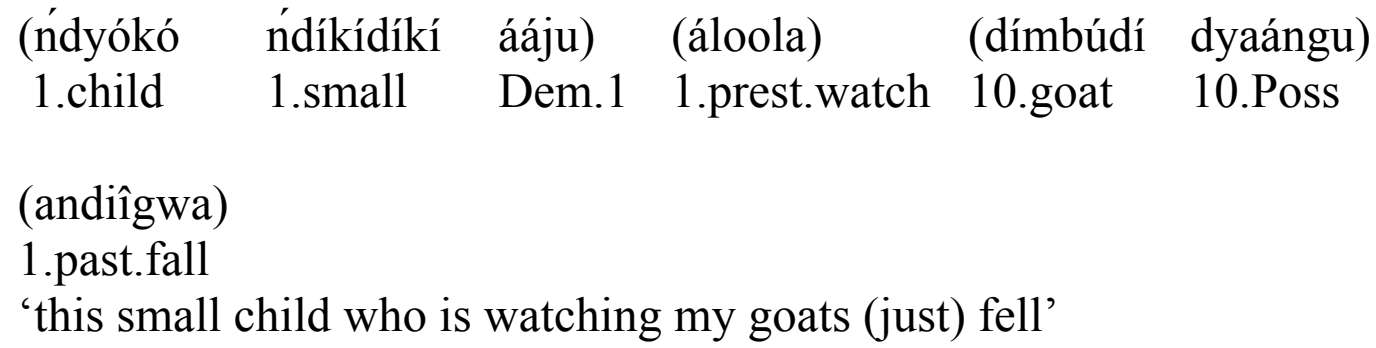

Interestingly, what is rather puzzling here is that the optional phrasing does not apply between the noun and its modifier as we saw in Section 3.2., but between the relative verb and its object noun phrase.

Before trying to explain this phenomenon, let us look at what happens when the relative verb is followed by a noun and an adjective (which, as we saw in Section 3, can never phrase with the noun it modifies).

$$
(\text { Noun + Adj + Dem })+(\text { Rel Verb + Obj Noun })+(\text { Adj })+(\text { Verb): }
$$

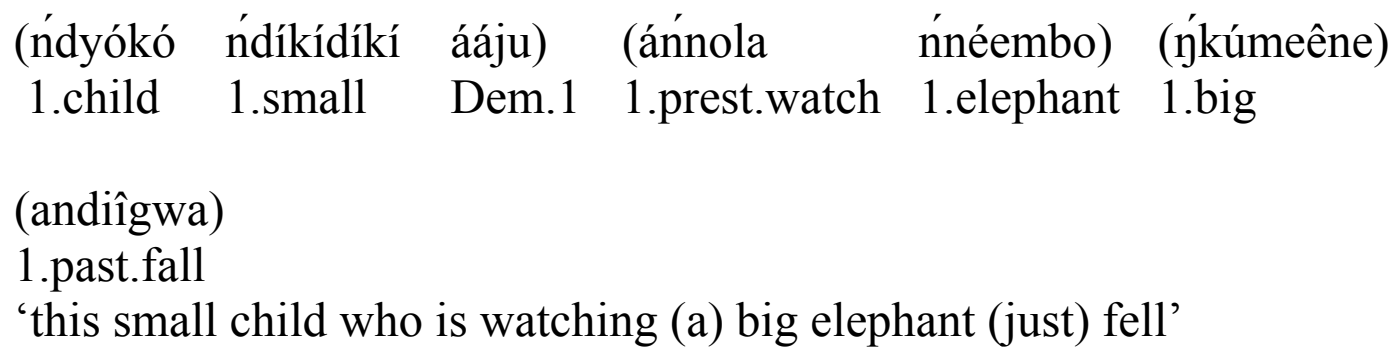

The relative verb and its object noun phrase together, without the adjective.

What happens now when a noun is followed by an adjective plus another modifier, for example a demonstrative (which always phrases with what precedes it)?

There are two phrasing options in this case: one where the adjective persists in phrasing separately (41) and the other one where the demonstrative - being in a final position this time - has, as we would expect, all that precedes it phrase in a single P-Phrase (42).

$($ Noun + Adj + Dem) + (Rel Verb + Obj Noun + Dem) + (Adj) + (Verb):

(41) (ńdyókó ńdíkídíkí ááju) (áńnola ńnémbó aiijá) (ýkúmeêne) 1.child 1.small Dem.1 1.prest.watch 1.elephant Dem1 1.big

(andiîgwa)

1.past.fall

'this small child who is watching that big elephant (just) fell' 
$($ Noun + Adj + Dem $)+($ Rel Verb + Obj Noun + Adj + Dem) + (Verb):

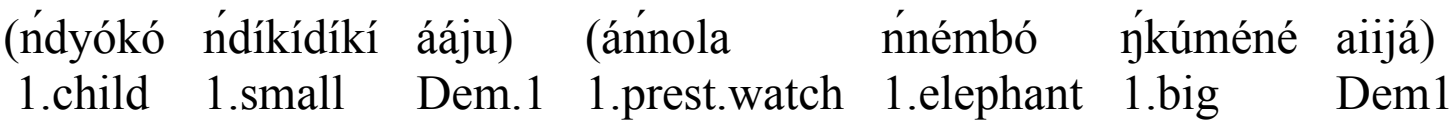

(andiîgwa)

1.past.fall

'this small child who is watching that big elephant (just) fell'

Let us look at other examples of an object noun followed by two modifiers, the last one still being a demonstrative.

$($ Noun + Adj + Dem) $+($ Rel Verb) $+($ Obj Noun + Poss + Dem $)+($ Verb):

\begin{tabular}{|c|c|c|c|c|c|}
\hline (ńdyókó & n'díkídíkí & ááju) & (áloola) & (dímbúdí & dyángú \\
\hline 1.child & 1.small & Dem. 1 & 1.prest.watch & 10.goat & 10.Poss \\
\hline adiilá) & (andiîgwa) & & & & \\
\hline Dem10 & 1.past.fall & & & & \\
\hline
\end{tabular}

The relative verb spontaneously appears with its disjoint form thus phrasing separately and the object noun and its two modifiers phrase together.

But the corpus shows that in this case the relative verb can also take its conjoint form and phrase with its object noun and the two modifiers that follow, as shown in (44) and (45).

$($ Noun + Adj + Dem $)+($ Rel Verb + Obj Noun + Num + Dem) + (Verb):

$\begin{array}{clllll}\text { (ńdyókó } & \text { ńdíkídíkí } & \text { ááju) } & \text { (álola } & \text { dímbúdí } & \text { mbílíi } \\ \text { 1.child } & 1 . \text { small } & \text { Dem.1 } & \text { 1.prest.watch } & 10 . \text { goat } & \text { Num10 }\end{array}$

áádi) (andî̂gwa)

Dem.10 1.past.fall

'this small child who is watching these two goats (just) fell'

13 Fast speech rate : (álola dímbúdí mbíly' áádi) (i > y). (cf. Manus (2003). 
$($ Noun + Adj + Dem $)+($ Rel Verb + Obj Noun + Poss + Dem $)+($ Verb):

\begin{tabular}{|c|c|c|c|c|c|}
\hline (ńdyókó & n'díkídíkí & ááju) & (álola & dímbúdí & dyángú \\
\hline $\begin{array}{l}\text { 1.child } \\
\text { adiilá) }\end{array}$ & $\begin{array}{l}\text { 1.small } \\
\text { (andiîgwa) }\end{array}$ & Dem.1 & 1.prest.watch & 10.goat & 10.Poss \\
\hline Dem10 & 1.past.fall & & & & \\
\hline
\end{tabular}

A relative verb phrasing with its object noun and the two modifiers that follow is also found in cleft relatives as shown in (46).

$($ ProN $)+($ Dem $)+($ Noun $)+\left(\right.$ Rel Verb + Obj Noun + Num + Dem $\left.^{14}\right):$

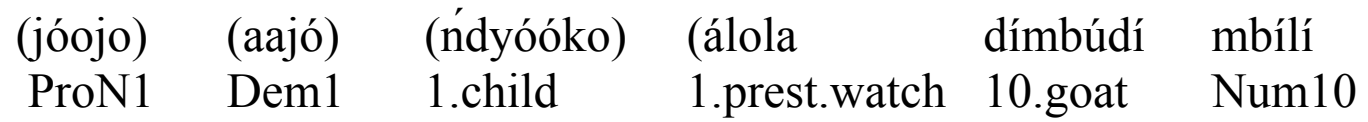

áádi)

Dem. 10

'this is the child who is watching these two goats'

Other clefts in the corpus show that the relative verb and its object do not necessarily phrase together in such contexts. The phrasing as a single P-Phrase and the conjoint form of the verb are not compulsory as we can see in the following examples. In (47) and (48), verb and object NP do phrase together constituting a single P-Phrase, whereas in (49) the verb and the object NP phrase separately.

$($ ProN $)+($ Dem $)+($ Noun $)+($ Rel Verb + Obj Noun $)$

(jóojo) (aajó) (ńdyóóko) (áńnola ńnéembo)
ProN1 Dem1 1.child 1.prest.OM1.watch 1.elephant 'this is the child who is watching (the) elephant'

$($ ProN $)+($ Dem $)+($ Noun $)+($ Rel Verb + Obj Noun + Poss $)$

(48) (jóojo) (aajó) (ńdyóóko) (álola dímbúdí dyaángu) ProN1 Dem1 1.child 1.prest.watch 10.goat 10.PossSG1 'this is the child who is watching my goats'

14 Keep in mind that a Noun Phrase ending with a demonstrative can phrase even if it contains 5 elements ie if the Noun is followed by 4 modifiers, as we saw above in (20). 
$($ ProN $)+($ Dem $)+($ Noun $)+($ Rel Verb $)+($ Obj Noun + Poss $)$

\begin{tabular}{|c|c|c|c|c|c|}
\hline (jóojo) & (aajó) & (ndyóóko) & (áloola) & (dímbúdí & dyaángu) \\
\hline ProN1 & Dem1 & 1.child & 1.prest.watch & 10.goat & 10.Poss \\
\hline
\end{tabular}

\section{Summary:}

Here is a summary and an analysis of phrasing in the Subject Relatives.

We will first look at what happens within the Subject Noun Phrase and between the Subject Noun Phrase and the relative verb.

Then we will look at what happens between the relative verb and its Object Noun Phrase.

\section{Subject Noun Phrase \& relative verb:}

The first two simple things to summarize concern the Subject Noun Phrase:

- the Subject Noun Phrase and the relative verb that follows always constitute two P-Phrases and can never phrase together as shown in (50):

\begin{tabular}{c}
2 P-Phrases: \\
(Subject NP) $+\quad($ Rel V) \\
and \\
$*($ Subject + Rel V) \\
\hline
\end{tabular}

- the Subject Noun Phrase itself behaves exactly as shown in Section 3, ie a Noun Phrase is generally parsed into more than one Prosodic Phrase when it contains more than one modifier, except if the last modifier is a demonstrative.

\section{Relative verb \& its object Noun Phrase:}

Between the relative verb and its object Noun Phrase, the alternation between phrasing together as a single P-Phrase and phrasing separately as two distinct PPhrases is a bit more complex and can be summarized as follows:

- as soon as there is an object noun following the relative verb, the relative verb always takes its conjoint form and phrases with its object noun,

- except if the relative verb is followed by at least two elements that can phrase together (an object noun followed by $\mathrm{x}$ modifiers with $\mathrm{x} \geq 1$ ). 
It works as if at least one of the phrasing options has to be fulfilled: the phrasing of the relative verb with its object noun or the phrasing of the object noun with its modifier(s).

(51) below summarizes the various phrasing possibilities between the relative verb and its Object Noun Phrase:

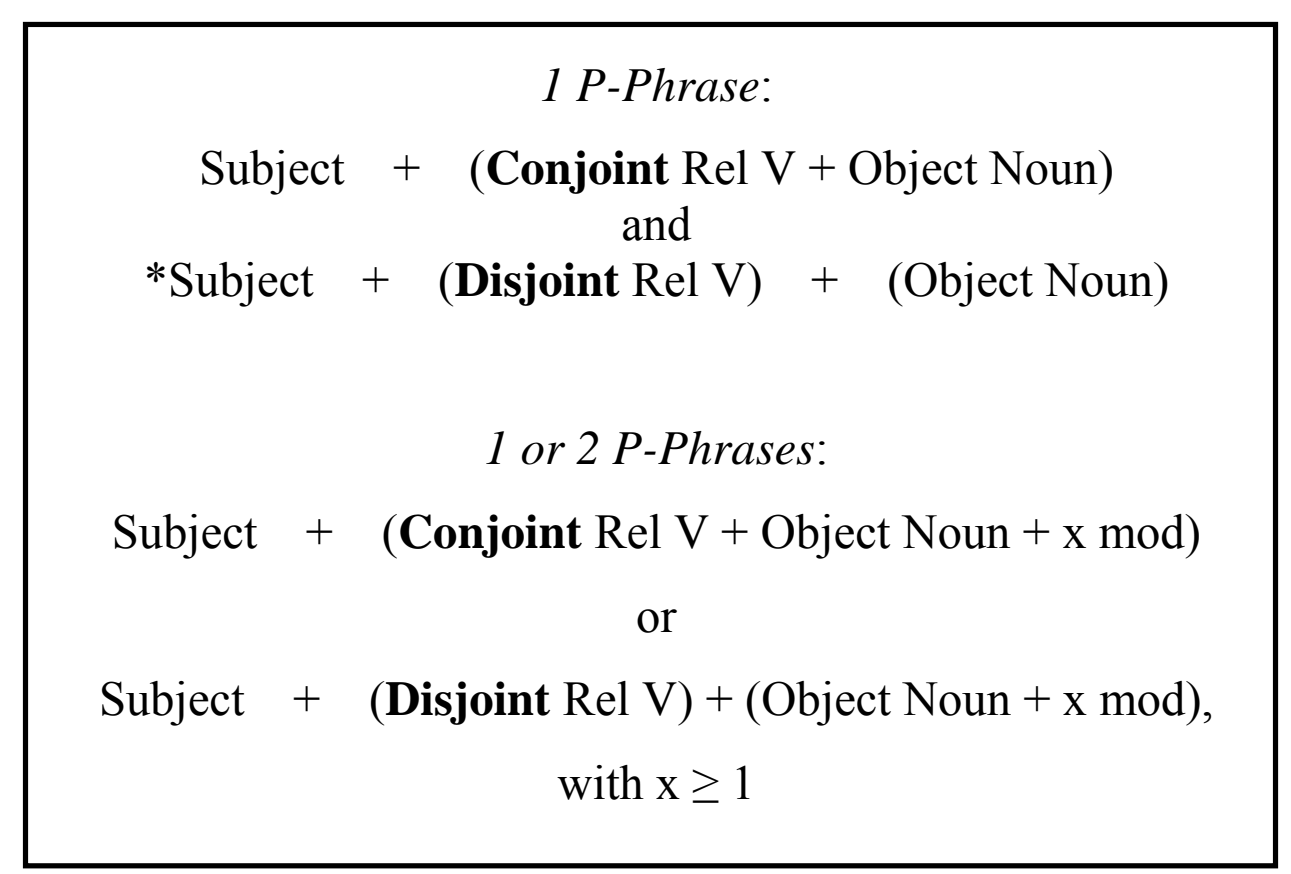

But of course the phrasing is not optional when the modifier is a type of modifier that can never constitute a single P-Phrase with what precedes, for example an adjective as shown in (40).

The structure will then be:

$$
(\text { Noun + Adj + Dem })+(\text { Rel Verb + Obj Noun })+(\text { Adj })+(\text { Verb }),
$$

with the adjective having to phrase separately as a distinct P-Phrase, unless there is a final demonstrative as shown in (42).

The structure will then be:

$$
(\text { Noun + Adj + Dem) + (Rel Verb + Obj N + Adj + Dem) + (Verb), }
$$

with the final demonstrative having everything that precedes phrase as a single P-Phrase.

This can be summarized as follows: 


$$
\begin{gathered}
2 \text { P-Phrases: } \\
\text { Subject }+\quad \begin{array}{c}
\text { Conjoint Rel V }+ \text { Object Noun })+(\bmod =\text { Adj }) \\
\text { because } *(\text { Noun }+ \text { Adj })
\end{array} \\
\text { unless the Adj is followed by a Dem: } \\
=>1 \text { P-Phrase: } \\
\text { Subject }+ \text { (Conjoint Rel V + Obj N + ADJ + Dem })
\end{gathered}
$$

\subsection{Object Relatives}

The prosody of Object relatives is much simpler than the one of Subject Relatives detailed above in 5.1.

Again, a noun followed by various modifiers phrases exactly as seen in Section 3 above.

We have seen that in a non-relative context, subject and verb never phrase, and that the head and the relative verb never phrase either in Subject Relatives. It is exactly the same for Object Relatives since *(Head + Rel Verb). Note that the pause (\# in the example below) between the head and the relative verb is often shorter than the pause (\#\#) between the relative verb and the verb that follows as shown in (53).

(Noun) + (CO + Rel Verb) + (Verb):

$$
\begin{aligned}
& \text { (ńdyóóko) \# (wá nínóola) \#\# (andiîgwa) } \\
& \text { 1.child 1.CO SG1.prest.OM1.watch 1.past.fall } \\
& \text { 'the child whom I am watching (just) fell' }
\end{aligned}
$$

Let us add modifiers to the Subject Noun Phrase.

$($ Noun + Poss + Dem $)+($ CO + Rel Verb $)+($ Verb $):$
(ńdyókú wángú
ááju) (wá úńnóola)
(andiîgwa)
1.child 1.possSG1 Dem.1 1.CO SG2.prest.OM1.watch 1.past.fall 'this child of mine whom you are watching (just) fell'

We will now look at other examples of Object Relatives exhibiting various other structures: a demonstrative as head and a post-posed Subject Noun in (55), an 
Object Noun with modifiers and a locative noun in (56), a Subject Noun, an Object Noun and a discourse deictic ${ }^{15}$ ) in (57).

$($ Dem) $+($ CO + Rel Verb) + (Subj Noun) + (Adj):

\begin{tabular}{|c|c|c|c|c|}
\hline (aviilá) & (vyá & vyásúuma) & (vádyóóko) & (vídíkídiîki) \\
\hline Dem8 & $8 . \mathrm{CO}$ & 8.prest.buy & 2.child & 8 small \\
\hline
\end{tabular}

$($ Verb $)+($ Obj Noun + Poss + Dem $)+($ CO + Rel Verb $)+($ Loc Noun $):$

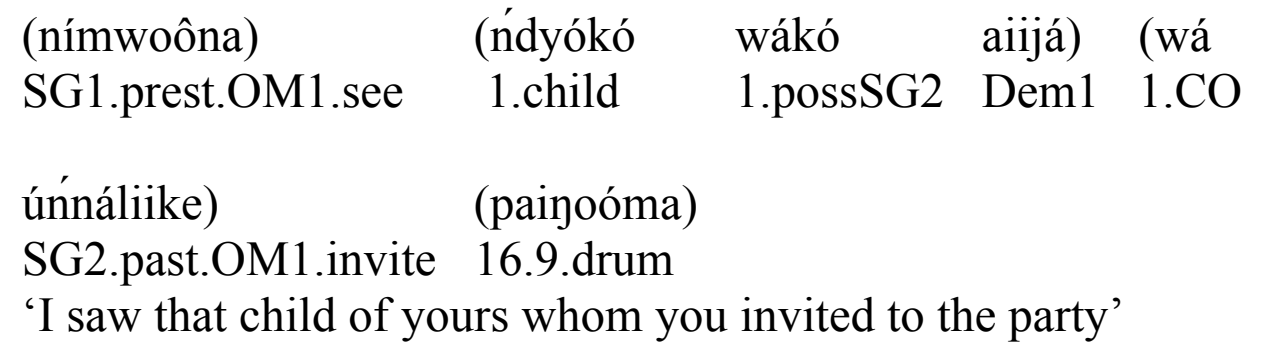

(Noun) + (CO + Rel Verb) + (Obj Noun) + (dis dei) + (Verb):

$\begin{array}{lllll}\text { (siloôngo) } & \text { (sá } & \text { tútálákeela) } & \text { (dyeénga) } & \text { (nasanaasó) } \\ \text { 7.pot } & \text { 7.CO } & \text { PL1.prest.cook } & \text { 10.rice } & \text { dis dei } 7\end{array}$

(sinditúmbuúka)

7.past.split

'The pot with which we cook the rice has split'

These three last examples show that the phrasing in Object Relatives is regular and as expected.

\section{Conclusion}

It has been shown that in Relative Clauses Head and Verb never phrase together and that the various Subject or Object Noun Phrases - made of a noun and one modifier or a noun and more than one modifier - follow the three different phrasing patterns exhibited in matrix clauses as well, since they can either form a single P-Phrase, or phrase separately in distinct P-Phrases, or optionally constitute a single P-Phrase or separate P-Phrases, depending on the quality of the modifiers and on their order.

15 Term proposed by G. Philippson, com. pers. 2010. Can be translated by "with it". 
It has also been shown that the prosody of Subject Relatives is more complex and unexpected than the one of Object Relatives, which is quite regular. Indeed, in Subject Relatives only, the relative verb can be either conjoint or disjoint, depending on what follows, with a minimal obligatory phrasing. The relative verb can be either conjoint and thus phrase with its Object noun when followed by an Object noun only, or phrase also with all the modifiers following the Object Noun if the last modifier is a demonstrative. Or the relative verb can be disjoint thus phrasing separately if the Object noun is followed by at least one element with which it can phrase.

It seems one of the two single P-Phrases is compulsory in this context: either the one between the relative verb and its Object NP or the one between the Object Noun and its modifier(s).

\section{References}

Buell, Leston. 2006. The Zulu Conjoint/Disjoint Verb Alternation: Focus or consistency? ZAS Papers in Linguistics Nr 43, Papers in Bantu Grammar and Description, 9-30.

Cheng, Lisa L.-S. \& Nancy Kula. 2006. Syntactic and phonological phrasing in Bemba Relatives. ZAS Papers In Linguistics Nr 43, Papers in Bantu Grammar \& Description, 31-44.

Cheng, Lisa L.-S. \& Laura J. Downing. 2007. The prosody \& syntax of Zulu relative Clauses. SOAS Working Papers In linguistics, Volume 15, 51-63.

Creissels, Denis. 1996. Conjunctive and disjunctive verb forms in Setswana, South African Journal of African Languages, 16(4), 109-115.

Creissels, Denis et al. 1997. Tonal Morphology of the Setswana Verb. LINCOM Studies in African Linguistics 13. Lincom Europa, München - Newcastle.

Devos, Maud. 2004. A Grammar of Makwe, PhD Dissertation. Leiden University.

Downing, Laura J. 2002. Fitting focus phrasing into the Prosodic Hierarchy. SOAS Working Papers in Linguistics, Vol. 12, 111-133.

Downing, Laura J., Al Mtenje \& Bernd Pompino-Marschall. 2004. Prosody and information structure in Chichewa. ZAS Papers in Linguistics 37, 167-186.

Downing, Laura J. \& Al Mtenje. 2007. The ordering and prosodic phrasing of nominal modifiers in Chichewa. The structure and interpretation of nouns and noun phrases: Bantu, Chinese, Romance, International Net-workshop 1, SOAS, 29 November - 1 December 2007.

Downing, Laura J. \& Al Mtenje. To appear. Prosodic phrasing of Chichewa Relative Clauses. $J A L L$.

Guthrie, Malcolm. 1948. The classification of the Bantu languages. Oxford University Press, $91 \mathrm{p}$. 
Hyman, Larry M. 1999. The Interaction between Focus and Tone in Bantu. In G.Rebuschi \& L.Tuller (eds.). The Grammar of Focus. Benjamins, Amsterdam, 151-177.

Hyman Larry M. \& Francis Katamba. 2005. The word in Luganda. In: F.K. Erhard Voeltz (ed.). Studies in African linguistic typology. John Benjamins, 171-193.

Hyman, Larry M. 2009. Penultimate Lengthening in Bantu: Analysis and Spread. Third Conference on Bantu Linguistics. Tervuren, March 2009, 25-27.

Kanerva, Jonni. 1990. Focus and Phrasing in Chichewa Phonology. New York: Garland.

Kraal, Peter. 2005. A Grammar of Makonde (Chinnima, Tanzania), PhD Dissertation. Leiden University.

König, Ekkehard \& Volker Gast. 2006. Focused assertion of identity: A typology of intensifiers. Linguistic Typology 10-2, 223-276.

Liphola, Marcelino M. \& David Odden. 2000. The tonal pattern of glides in Shimakonde. In: Theoretical approaches to African linguistics IV. V. Carstens \& F. Parkinson (eds.). Red Sea Press, New Brunswick, 177-188.

Liphola, Marcelino M. 2001. Aspects of Phonology and Morphology of Shimakonde, PhD Dissertation. Ohio State University.

Manus, Sophie. 2003. Morphologie et Tonologie du Símákonde, parlé par les communautés d'origine mozambicaine de Zanzibar et de Tanga (Tanzanie), PhD Dissertation. Institut National des Langues et Civilisations Orientales.

Manus, Sophie. 2007. Phrasal Tone \& the Conjoint / Disjoint distinction in Símákonde. Invited Talk, Zentrum für Allgemeine Sprachwissenschaft (ZAS), Berlin.

Manus, Sophie. 2009. Complex Phrasing in the Símákonde Noun Phrase. Third Conference on Bantu Linguistics, Tervuren, March 25-27, 2009.

Maho, Jouni. F. 2003. A classification of the Bantu languages: an update of Guthrie's referential system. In: Derek Nurse \& Gérard Philippson (eds). The Bantu Languages. London / New York, Routledge, 639-651.

Odden, David. 1990a. Tone in the Makonde dialects: Chimaraba. Studies in African linguistics 21, 61-105.

Odden, David. 1990b. Tone in the Makonde dialects: Chimahuta. Studies in African linguistics 21, 149-187.

Odden, David. 1990c. C-command or edges in Makonde. Phonology 7, 163-169.

Odden, David. 2003. Rufiji-Ruvuma (N10, P10-20). In: Derek Nurse \& Gérard Philippson (eds). The Bantu Languages. London / New York, Routledge, 529-545.

Patin Cédric \& Annie Rialland. 2006. On the nature of rules sensitive to syntax: the case of Makonde tonology. In: Iván Fónagy, Yuji Kawaguchi \& Tsunekazu Moriguchi (eds.). Usage-based linguistic informatics 3. John Benjamins: Amsterdam, 285-301.

Patin, Cédric. 2007. La tonologie du shingazidja, langue bantu (G44a) de la Grande Comore: nature, formalisation, interfaces, PhD Dissertation. Université Sorbonne nouvelle Paris 3. 
Patin, Cédric. 2010. The Prosody of Shingazidja Relatives. Relative Clauses in Bantu, Workshop, Paris.

Truckenbrodt, Hubert. (1999). On the relation between syntactic phrases and phonological phrases. Linguistic Inquiry 30, 219-255.

Zerbian, Sabine. 2004. Phonological Phrases in Xhosa (Southern Bantu). ZAS Papers in Linguistics $\mathrm{Nr}$ 37, 71-99. 